\title{
Using the novel priority index in prioritizing the selection of inland water bodies for site-based fish species conservation
}

\author{
Anthony Basooma ${ }^{1}$, Herbert Nakiyende ${ }^{1}$, Mark Olokotum ${ }^{1}$, Winnie Nkalubo ${ }^{1}$, Laban \\ Musinguzi ${ }^{1}$, and Vianny Natugonza ${ }^{1}$ \\ ${ }^{1}$ Affiliation not available
}

November 12, 2020

\begin{abstract}
Freshwater ecosystems occupy $<1 \%$ of the Earth's total surface area but provide an array of ecosystem services. However, these ecosystems are threatened by multiple stressors, including overexploitation, infrastructure developments, habitat alteration, and alien species introductions. The magnitude of these threats varies in different water bodies, requiring site-based conservation actions. In this paper, we aimed at developing a priority index (CPIw) that can be used to inform conservation managers in prioritizing the selection of a waterbody for site-based fish conservation purposes. We used data on distribution, diversity, and conservation status of fishes of Uganda, which were retrieved from the Global Biodiversity Information Facility (GBIF) and International Union Conservation for Nature (IUCN) databases. In the index, we incorporated the species richness, surface area of a waterbody, species rarity, and species IUCN status. A total of 288 fish species were recorded in 81 waterbodies $(7$ large lakes, 37 small lakes, and 37 rivers). Of these species, 110 were only found in large lakes, followed by rivers (19) and small lakes (6). Despite the higher species richness in large lakes relative to small lakes, the latter recorded significantly higher CPIw compared with the former $(\mathrm{t}=-2.8, \mathrm{df}=30, \mathrm{p}$-value $=0.008, \mathrm{~d}=0.7)$. This observation is consistent with the expectation, given the low ecological substitutability for the species and higher levels of exposure to human-induced threats in small water bodies compared with large systems. Therefore, we suggest that in situations where resources are limiting, small water bodies need to be given much attention, although we do not suggest ignoring water bodies with low CPIw values.
\end{abstract}

\section{Introduction}

Freshwaters constitute $\sim 3 \%$ of the Earth's water (WWF 2020) and occupy $<1 \%$ of the Earth's surface area (Garcia-Moreno et al. 2014), but is habitat to about $40 \%$ of all described fish species (Lundberg et al. 2000). The benefits of these freshwater resources to society are immense. For example, 21 largest lakes in the world provide about 1.3 million tons of fish annually, $62.5 \mathrm{GW}$ of hydropower, 5 billion $\mathrm{m}^{3}$ of potable drinking water, and 815 million $\mathrm{m}^{3}$ of water for irrigation (Sterner et al. 2020). Also, freshwater systems replenish estuarine, oceans, and seas with nutrients and water (Matthews 2016); for example, Nile River deposits 1318 and $212 \mathrm{~kg} \mathrm{~km}^{-2} \mathrm{yr}^{-1}$ of nitrogen and phosphorus, respectively, into the Mediterranean Sea (Yasin et al. 2010).

Freshwater species are more susceptible to human-induced threats such as climate change, pollution, habitat alteration, overexploitation, and alien species introductions compared with marine and terrestrial species (Darwall et al. 2018; WWF 2020). For example, while marine and terrestrial species have declined by $39 \%$ in the last 50 years, freshwater counterparts have reduced by $76 \%$ higher than the global average of $52 \%$ (WWF 2014). Freshwater fish species might be the most threatened vertebrates assessed by IUCN (Reid et al. 2013). The species are affected by the high levels of exploitation to support about 158 million people worldwide who derive animal protein from freshwater fish species (McIntyre et al. 2016). 
Approximately 500 fish species are reported in all water bodies in Uganda (NEMA 2007; Natugonza \& Musinguzi, 2020). However, several non-native fishes, including Nile perch (Lates niloticus), Nile tilapia (Oreochromis niloticus), redbelly tilapia (Coptodon zillii), blue-spotted tilapia (Oreochromis leucostictus ), and redbreast tilapia (Coptodon rendalii) were introduced into various lakes and rivers within the Victoria and Kyoga lake basins (Kishe-Machumu et al. 2018). These introductions especially for Nile perch coincided with the collapse of most native fish species (Ogutu-Ohwayo 1990). In Lake Victoria, $\sim 300+$ haplochromine cichlids were extirpated (Kaufman 1992; Ogutu-Ochwayo 1990), and similar destructive ecological changes were observed in lakes Kyoga and Nabugabo (Ogutu-Ohwayo 1990; Chapman et al. 1996). This loss in haplochromine cichlids is believed to be the worst vertebrate species extinction observed in recent times (Kaufman 1992), placing Nile perch among the 100 top worst alien invasive species in the world (Lowe et al. 2000). Other native species such as Singidia tilapia (Oreochromis esculentus) and Ningu (Labeo victorianus ), which previously dominated in fish catches from Lake Victoria and its affluent rivers (Kudhongania et al. 1992) are currently classified as critically endangered (IUCN 2020). The catfishes, including Semutundu (Bagrus docmak Forsskål, 1775), Lake Victoria deepwater catfish (Xenoclaris eupogon), Clarias spp. ,Synodontis spp., and Silver catfish (Schilbe intermedius ) were also affected by Nile perch establishment in Lake Victoria (Goudswaard \& Witte 1997; Balirwa 1998; Balirwa et al. 2003). Riverine species were mostly affected by overexploitation and habitat degradation, while the native tilapines declined mostly through interspecific competition and hybridization (Cadwalladr 1965; Kudhongania et al. 1992).

The reduction in fish species diversity in Uganda has led to numerous studies focussing on the species diversity, abundances, distribution, taxonomy, and biology of the remnant species to facilitate their recovery and reduce further extinctions (Witte \& Van Oijen 1990; Kaufman \& Ochumba 1993; Ogutu-Ohwayo 1993; Ogutu-Ohwayo et al. 1999; Mbabazi et al. 2004). In particular, small lakes, swamps, rivers, streams, and wetlands were documented as the main structural refugia for these fishes (Ogutu-Ohwayo et al. 1999; Mwanja et al. 2001; Chapman et al. 2002; Mbabazi et al. 2004; Balirwa et al., 2003; Wakwabi et al. 2006; Olwa et al., 2020). However, these studies were waterbody-specific with limited information to rank the waterbodies for site-based conservation given the limited available resources. Analysis of the distribution of fishes at a broader scale has been limited in the past due to the paucity of data, which have been scattered in many research institutions in unusable formats. Recently, substantial amounts of data on the occurrence of fishes for Uganda have been made available through the Global Biodiversity Information Facility portal (GBIF) (GBIF, 2020). This study aims to develop a Conservation Priority Index (CPIw) for inland water bodies to prioritize their selection for site-based fish conservation, especially when resources are limiting. We use data on the distribution, diversity, and conservation status of the fish species in Uganda, which are freely accessible through GBIF and IUCN databases.

\section{Methods}

\section{Data acquisition and processing}

We retrieved occurrence records from two fish classes (Actinopterygii and Sarcopterygi) in Ugandan water bodies from GBIF online data repository (GBIF 2020). We used the occ_download_get function in rgbif package to retrieve data (Chamberlain et al. 2020). Except for genera Astatoreochromis and Pseudocrenilabrus , we changed all other haplochromine cichlids genera to Haplochromisto conform with FishBase nomenclature (Froese \& Pauly 2019), which is based on Oijen (1996). Thus, names such as Astatotilapia nubilawere changed to Haplochromis nubilus ; Schubotzia eduardiana to H. eduardianus ; and Astatotilapia pallida to H. pallidus . Occurrences that were outside the geographic range described in FishBase, and whose identity could not be verified based on recent survey data, were discarded. We also excluded all occurrences without complete scientific names (genus and specific epithet), e.g., Haplochromis sp. and Oreochromis sp. Occurrences with unknown and incorrect water bodies were excluded, e.g., all records of $H$. eduardii that were recorded in Lake Albert in the GBIF datasets were discarded, as the species is endemic to Lake Edward (Froese \& Pauly 2019). For occurrence records without a named waterbody of origin but with coordinates were determined 
based on the GPS coordinates. We used habitat descriptions, verbatim locality, and location remarks to identify the waterbody of origin. We also discarded all occurrences from manmade water bodies, such as ponds, tanks, and aquarium. Lakes Salisbury and Kasudho were changed to Bisina and Kasodo, respectively, to conform to the current names and avoid duplication of records for the same lakes. We categorized lakes $<200 \mathrm{~km}^{2}$ as small lakes and $>200 \mathrm{~km}^{2}$ as large lakes, resulting in 7 large and 37 small lakes (Appendix S1 and S2). After preliminary processing of the data, a total of 14,452 occurrences records were retained for further analysis.

\section{Conservation priority index formulation}

We retrieved the conservation status of each species from the International Union for Conservation of Nature (IUCN) Redlist database (www.iucnredlist.org/). The species are classified as data deficient (DD), least concern (LC), critically endangered (CR), near threatened (NT), endangered (EN), and not evaluated (NE) (IUCN 2012). We used waterbody surface area, species richness, IUCN statuses, rarity, and scaling constant to develop the conservation priority index (CPIw), based on the formula:

$$
\mathrm{CPIw}=\frac{\sum_{\mathrm{i}=1}^{\mathrm{n}} \mathrm{Cwt}_{\mathrm{i}} \cdot \mathrm{R}_{\mathrm{i}}}{(\mathrm{Aw} \cdot 7)}
$$

where, for species $i$ per unit surface area of a waterbody, $\mathrm{Cwt}_{\mathrm{i}}$ is the species weight based on its IUCN status (i.e., CR (5), EN (4), VU (3), NT (2), LC (1)); n is the number of species in a particular waterbody; Aw is the total surface area of the lake, and Ri is the frequency of occurrence of a species in the water bodies (i.e., if a species occurred in one waterbody, then a weight of 5 was assigned, 2-3 water bodies (weight 4), 4-5 water bodies (weight 3), 6-10 water bodies (weight 2), and $>10$ water bodies (weight 1 )). The value 7 is a scaling constant, indicating the total number of IUCN categories (IUCN, 2012). Note that fish species that were registered as NE and DD in the IUCN database were assigned a $\mathrm{Cwt}_{\mathrm{i}}$ of 5 on the basis that such species can go extinct unnoticed and, therefore, should be considered in the same category as CR species (IUCN 2012). The surface area for each lake was obtained from the literature (Burgis \& Symoens 1987; Vanden Bossche \& Bernacsek 1990; Ogutu-Ohwayo et al. 1999; Schofield \& Chapman 1999; Olowo et al. 2004). We used Google Earth to approximate the surface area for lakes Gawa, Kabaleka, Wamala, Nakabale, Owapet, Kirimira, and Kabaka because it was not found in the literature. The surface area of Lakes Natuali, Chankaranga, Okurachere, Kasunju, Nkuruba, and Mutabyo could not be determined from both literature and Google Earth, and thus we could not calculate their CPIw values.

\section{Data analysis}

For each water body category (small lakes, large lakes, and rivers), we determined the species richness and the total number of species in IUCN status categories. We used a non-parametric Kruskal Wallis test to assess the mean differences in the species richness and IUCN categories among waterbody categories. Post hoc multiple comparisons were conducted with a Dunn's test to determine the statistical differences between the waterbody categories. We generated a species accumulation curve for the waterbody to assess if most of the species found in the data. We determined the rarity of a particular species by summing the frequency of occurrence in the water bodies where it was found. We used the Bray Curtis dissimilarity measure to compute the ranks for water bodies and species and later used a non-metric multidimensional scaling (nMDS) to visualize the species and water bodies in 2-D ordination space. After, we performed an analysis of similarity (ANOSIM) to determine the statistical differences among waterbody categories. A similarity percentage analysis (Simper) was used to evaluate the contribution of the species to the dissimilarities between waterbody categories.

For the index, we log-transformed the CPIw values and used a Shapiro-Wilk and Levene tests to examine for normality and equality of variance, respectively. After, we used a parametric Welch 2-Sample t-test to evaluate the differences between the mean CPIw values for large and small lakes. We processed data with predefined functions in $\mathrm{R}$ (including specaccum, diversity, metaNMDS, simper, anosim, ) of the Vegan package (Oksanen et al. 2019), dunn test in Dunn package (Dinno, 2017). 


\section{Results}

\section{Species composition and rarity}

A total of 288 species were recorded from 81 water bodies (i.e., 7 large lakes, 37, small lakes, and 37 rivers) (Fig 1 \& Appendix S2). Of the 288 species, 163 were haplochromine cichlids and 125 non-haplochromine. The species accumulation curve increased at a low rate after 20 water bodies (Fig 2). All haplochromine cichlids were recorded in 45 water bodies compared with 75 for non-haplochromines. Species richness was highest in large lakes dominated by Lake Victoria with 175 species followed by Albert, Kyoga, and George (Fig 1, Appendix S2). Kruskal Wallis test showed that waterbody categories differed significantly in mean species richness, and the IUCN status categories (Table 1). However, the nature of a waterbody had a weak effect on the variation in species richness and IUCN categories (Table 1). Post hoc multiple comparisons showed that large lakes were significantly different from rivers and small lakes for all IUCN categories and species richness. However, except for the vulnerable category, rivers and small lakes were not significantly different (Table 1).

Of the 163 haplochromine cichlids, 85 species were found in utmost one waterbody compared with 31 non-haplochromine species (Fig 3). Lake Victoria had 71 rare species, where 11 were critically endangered haplochromine cichlids and one non-haplochromine species (Xenoclarias eupogon ) (Appendix S3). Two near threatened species (H. labiatus and H. oregosoma) were only found in the interconnected system of lakes George, Edward, and Kazinga Channel.Clarias gariepinus was found in 42 water bodies followed by Enteromius kerstenii, O. niloticus (33), andProtopterus aethiopicus (32). Astatoreochromis alluaudiwas recorded in 30 water bodies, $H$. nubilus (28), H. lividus (16), H. argenteus (14), H. phytophagus (13),H. obesus (12), and H. parvidens in (11). Oreochromis esculentus was observed in 19 water bodies, O. variabilis (15), and L. victorianus (8). Based on IUCN categories, no vulnerable non-haplochromines was found in Lake Victoria; however, 8 of the 25 vulnerable haplochromine cichlids were only recorded in the lake (Appendix S3). Labeobarbus ruwenzorii and $L$. alluaudi were only found to Lake Edward and rivers Ivi, Rutushuru, Rwimi, Sebwe, Rwenzori, and Mubuku). Nothobranchius taeniopygus and Synodontis macrops were only found in Aswa River. H. melanopterus was recorded in Lake Kasodo whereasH. commutabilis and H. ampullarostratus were only found in Lake Kachiira (Appendix S3). Of the endangered fish species, Astatotilapia desfontainii was only recorded in lakes Bisina, Victoria, and Victoria Nile; H. simpsoni was only found in lakes Kyoga, Nabugabo, and Kayanja, while Lates macrophthalmus was only recorded in Lake Albert. $H$. beadlei, a critically endangered species, was found in lakes Nabugabo and Victoria, and H. grantiin Lake Victoria and River Kagera.

Among the 3 waterbody categories, large lakes recorded the highest number of non-shared species (110), followed by rivers (19), and the small lakes (6) (Fig 4). The species richness in waterbody categories differed significantly (Kruskal Wallis: $\chi^{2}=18.6, \mathrm{df}=2, \mathrm{p}=0.001, \eta^{2}=0.2$ ). The nMDS had a stress level of 0.14, with large and small lakes closely clustered except rivers (Appendix S4). Haplochromine cichlids were closely clustered, except $H$. latifasciatus, H. victoriae, A. alluaudi, H. nubilus, and H. schubotzi, while non-haplochromine species were widely distributed (Appendix S5). Analysis of similarity (ANOSIM) among waterbody categories showed significant differences $(\mathrm{R}=0.24, \mathrm{p}<0.001)$. Similarity percentage (simper) analysis showed that large lakes differed from small lakes (93.5\%) and rivers (97.5\%), while small lakes differed from rivers by $96.2 \%$. Lates niloticus and $O$. niloticus contributed the highest average percentage variation between large lakes and rivers. Similarly, L. niloticus had the highest contribution between large and small lakes (Appendix S6). In contrast, A. alluaudi and C. gariepinus had the highest contribution to the variation between rivers and small lakes.

\section{Conservation Priority Index (CPIw)}

CPIw was computed for 38 lakes, where 7 were large lakes and 31 small lakes. Small lakes had a mean CPIw of 2.4 (SD 4.6) compared with 0.05 (SD 0.04) for large lakes. A significant difference between the mean 
CPIw value for large and small lakes was observed (Welch 2-Sample t-test: $\mathrm{t}=-2.8, \mathrm{df}=30$, $\mathrm{p}$-value $=$ $0.008, \mathrm{~d}=0.7)$. The surface area of the lakes had a large effect on the CPIw values. Highest CPIw values were recorded for lakes Manywa followed by Kayanja, Gigate, Agu, Naragaga, Kawi, and Nabugabo (Fig 5 \& Appendix S7). Low values were mostly recorded for large lakes and highest for small lakes.

\section{Discussion}

\section{Species composition, rareness, and distribution}

The total species count recorded was comparable with the FishBase overall estimate of 278 described fish species in Uganda (Froese \& Pauly 2019). Also, the species accumulation curve approached the asymptote, suggesting that most of the species were considered in the analysis (Gotelli \& Colwell 2001). Large lakes had higher species richness and more rare species compared with rivers and small lakes. Differences in species richness and rarity among water bodies may be attributed to geomorphological, abiotic, and biotic factors (Brown et al. 2007). Also, isolated inland water bodies favor rapid allopatric speciation and adaptive radiation (Basiita et al. 2018), which exposes the species to different evolutionary pressures. For example, along the Victoria Nile, Murchison Falls hinders fish migration to Lake Kyoga from Albert (Basiita et al. 2018). The falls along River Semiliki prevents fish passage to Lake Albert from Edward (Acere \& MweneBeyanga 1990). Similarly, between Lake Victoria and Kyoga have been separated by the Owen and Bujagali falls (Basiita et al. 2018), and a sandbar between Lake Nabugabo and Victoria (Stager et al. 2005). These biogeographical barriers may have led to allopatric speciation; for instance, Lake Nabugabo which was once connected to Lake Victoria had five endemic species (Ogutu-Ohwayo 1993; van Alphen et al. 2004). At the species level, L. niloticus from lakes Kyoga and Victoria were genetically different (Basiita et al., 2018) possibly due to manmade barriers between the two lakes, which has impeded gene flow (Basiita et al. 2018).

High species richness and rarity are expected in habitats of long geological age, geographically isolated, and where species are prone to speciation (Strayer 2013). Also, according to the biogeographical principle, large areas have more species (Rosenzweig 1995). In this study, the high species richness and rareness observed in Lake Victoria is not surprising, given its surface area, explosive speciation and adaptive radiation of haplochromine cichlids because of hybridization, allopatric, microallopatric and sympatric mechanisms (van Alphen et al. 2004; Meier et al. 2017). A similar trend of high species richness with increased lake area was observed (Amarasinghe \& Welcomme 2002). In large water bodies, species can shift to favorable habitats, for example, Squalius lucumonis and Telestes muticellus that migrated upstream in the Mediterranean Rivers due to climate warming (Carosi et al. 2019). The level of rarity of recently described species could not be determined in the available data. For example, the distributions of $H$. akika in Lake George (Lippitsch 2003) and H. katonga in River Katonga (Schraml \& Tichy 2010) are not well understood except where the specimen was obtained. Also, haplochromine cichlids are mostly lumped as haplochromines (Marshall 2018), which may have accounted for the absence of certain species in particular water bodies.

For rivers, habitat degradations and manmade obstructions mostly damming have affected fish species migration, feeding, and recruitment patterns (FAO 2001). For instance, only 70 of the 177 large rivers in the world are free from damning (WWF, 2020). In Uganda, along the Upper Victoria Nile, three dams were constructed. These obstructions affected species richness and gene flow along the river (Basiita et al., 2018). For example, the stocks of $H$. simotes and $L$. victorianus have been affected by dams along the Upper Victoria Nile (Sayer et al. 2018). Similar effects of damming have been reported along Yangtze and Mekong (Dugan et al. 2010; Yi et al. 2010).

\section{Conservation Priority Index (CPIw) for inland water bodies}

Biological metrics including indices, indicators, or targets have been used by managers and decision-makers to prioritize areas for conservation (Tognelli et al. 2019; Linke et al. 2011). These metrics may include 
prioritizing areas with threatened species (Kirkpatrick 1983), threatened species affected by climate change (Tognelli et al. 2019), or fixed percentages of an area (Linke et al. 2011). However, some indices such as species richness do not incorporate the component of complementarity of the areas in question, thus, highly-ranking areas with the same species (Kirkpatrick, 1983). Shannon Weaver diversity index does not distinguish habitats with the same species evenness and richness (Omayio \& Mzungu, 2019). Most priority indices are computed for terrestrial ecosystems or specific for a particular region, thus, cannot be extrapolated to other systems (Brum et al. 2017). For example, the Forest Conservation Priority index (FCPI) (de Mello et al. (2016) used the area and shape of the forest without considering the species conservation status. The Cave Conservation Priority Index (CCPi) (Souza Silva et al. 2014) did not consider the species or their conservation status but species richness, distribution, and impact weights. In the species conservation importance index, the species conservation status and rarity were considered (Halmy \& Salem, 2015), but the index applied to terrestrial plants but not an aquatic ecosystem. Thus, these priority indices cannot be used to rank water bodies for site-based priority conservation.

In most instances, biodiversity measures such as species richness are usually higher for large water bodies, which would mean they are prioritized for conservation. Indeed, this study also showed higher species richness for large lakes compared to small ones. However, the novel conservation priority index (CPIw) was significantly higher for small lakes compared with large lakes. This observation is consistent with expectation, given the low ecological substitutability for the species and higher levels of exposure to human-induced threats in small water bodies compared to large systems. For a system such as Lake Victoria, with a vast habitat heterogeneity, fish species can easily seek refugia in other habitats (Seehausen et al. 1997; Chapman et al. 2003), which may not be possible in a small water body. The index showed that, for example, Lake Gigate with a surface area of $1.7 \mathrm{~km}^{2}$, but with 4 critically engendered haplochromine cichlids $(H$. latifasciatus, $H$. obesus, $H$. parvidens, and $H$. argenteus ) could be prioritized for conservation ahead of a large system with higher species richness. The likelihood of the species getting extinct in Lake Gigate is eminent if a similar magnitude of stress is applied to both lakes. However, the index does not imply that other water bodies with low CPI should not be monitored, but it may allow a conservation manager or decision makers to rank water bodies for urgent intervention, especially if the resources are limiting. Because conservation interventions should address social needs (Linke et al., 2011), large waterbodies, which are usually productive would be difficult to fully conserve. The index should, therefore, be adopted as a rapid metric measure to rank water bodies to enable prioritizing them for conservation. Further, if the size and species in habitats in the waterbody are known, the index can be downscaled to a habitat level. However, index could not be applied on rivers because most of them are dammed or obstructed, creating distinctive habitats along the river.

\section{Supporting Information}

The map large lakes in Uganda (Appendix S1), Waterbody species richness and IUCN status (Appendix S2), Rare species (Appendix S3), Ordination plot for waterbodies (Appendix S4). Ordination plot for species (Appendix S5), Simper analysis plot (Appendix S6), Waterbody Conservation priority index values (Appendix S7)

\section{Literature cited}

Acere, T. O., \& Mwene-Beyanga, P. (1990). Lake Albert Fisheries Resources and Their Management Strategy . Retrieved from https://core.ac.uk/download/pdf/78049125.pdf

Amarasinghe, U. S., \& Welcomme, R. L. (2002). An Analysis of Fish Species Richness in Natural Lakes. Environmental Biology of Fishes , 65 (11), 327-339. DOI: 10.1023/A

Balirwa, J. S., Chapman, C. A., Chapman, L. J., Cowx, I. G., Geheb, K., Kaufman, L., .. Witte, F. (2003). Biodiversity and Fishery Sustainability in the Lake Victoria Basin: An Unexpected Marriage? BioScience, 53 (8), 703-715. DOI: 10.1641/0006-3568(2003)053[0703:bafsit]2.0.co;2 
Balirwa, John Stephen. (1998). Lake victoria wetlands and the ecology of the Nile tilapia Oreochromis niloticus linné . Wageningen Agricultural University. DOI: 10.4324/9780203749630

Basiita, R. K., Zenger, K. R., Mwanja, M. T., \& Jerry, D. R. (2018). Gene flow and genetic structure in Nile perch, Lates niloticus, from African freshwater rivers and lakes. PLoS ONE , 13 (7), 1-21. DOI: 10.1371/journal.pone.0200001

Brown, R. L., Jacobs, L. A., \& Peet, R. K. (2007). Species Richness: Small Scale. Encyclopedia of Life Sciences , 1-8. DOI: 10.1002/9780470015902.a0020488

Brum, F. T., Graham, C. H., Costa, G. C., Hedges, S. B., Penone, C., Radeloff, V. C., ... Davidson, A. D. (2017). Global priorities for conservation across multiple dimensions of mammalian diversity.PNAS , 114 (29), 7641-7646. DOI: 10.1073/pnas.1706461114

Burgis, M. J., \& Symoens, J. J. (1987). African wetlands and shallow water bodies. (1st ed.). Paris, France.

Carosi, A., Padula, R., Ghetti, L., \& Lorenzoni, M. (2019). Endemic freshwater fish range shifts related to global climate changes: A long-term study provides some observational evidence for the Mediterranean area. Water , 11 (11), 1-20. DOI: 10.3390/w11112349

Chamberlain, S., Barve, V., Mcglinn, D., Oldoni, D., Desmet, P., Geffert, L., \& Ram, K. (2020). rgbif: Interface to the Global Biodiversity Information Facility API_. R package version 2.2.0. Retrieved from https://cran.r-project.org/package=rgbif\%3E

Chapman, L. J., Chapman, C. A., Ogutu-Ohwayo, R., Chandler, M., Kaufman, L., \& Keiter, A. E. (1996). Refugia for endangered fishes from an introduced predator in Lake Nabugabo, Uganda. Conservation Biology , 10 (2), 554-561. DOI: 10.1046/j.1523-1739.1996.10020554.x

Chapman, L. J., Chapman, C. A., Schofield, P. J., Olowo, J. P., Kaufman, L., Seehausen, O., \& OgutuOhwayo, R. (2003). Fish faunal resurgence in Lake Nabugabo, East Africa. Conservation Biology , 17 (2), 500-511. DOI: 10.1046/j.1523-1739.2003.01519.x

Darwall, W., Bremerich, V., Dell, A. I., Gessner, M. O., Jähnig, S. C., Grossart, H. P., .. Tockner, K. (2018). The Alliance for Freshwater Life: A global call to unite efforts for freshwater biodiversity science and conservation. Aquatic Conservation: Marine and Freshwater Ecosystems , (7), 1-8. DOI: 10.1002/aqc.2958

de Mello, K., Toppa, R. H., \& Cardoso-Leite, E. (2016). Priority areas for forest conservation in an urban landscape at the transition between Atlantic Forest and Cerrado. Cerne , 22 (3), 277-288. DOI: $10.1590 / 01047760201622032172$

Dinno, A. (2017). dunn.test: Dunn's Test of Multiple Comparisons Using Rank Sums. R package version 1.3.5. CRAN Repository . Retrieved from https://cran.r-project.org/web/packages/dunn.test/dunn.test.pdf

Dugan, P. J., Barlow, C., Agostinho, A. A., Baran, E., Cada, G. F., Chen, D., .. Winemiller, K. O. (2010). Fish migration, dams, and loss of ecosystem services in the Mekong basin. Ambio ,39 (4), 344-348. DOI: $10.1007 / \mathrm{s} 13280-010-0036-1$

FAO. (2001). Dams, Fish, and Fisheries: Opportunities, Challenges, and Conflict Resolution (No. 419). FAO Fisheries Technical Paper. Retrieved from http://www.fao.org/3/Y2785E/y2785e03.html

Froese, R., \& Pauly, D. (2019). FishBase. Retrieved July 29, 2020, from www.fishbase.org

Garcia-Moreno, J., Harrison, I. J., Dudgeon, D., Clausnitzer, V., Darwall, W., Farrell, T., ... Tubbs, N. (2014). Sustaining Freshwater Biodiversity in the Anthropocene. In A. Bhaduri, J. Bogardi, S. Marx, \& J. Leentvaar (Eds.), The Global Water System in the Anthropocene Challenges for Science and Governance (p. 28). Springer International Publishing Switzerland 2014. DOI: 10.1007/978-3-319-07548-8

GBIF. (2020). GBIF Occurences. DOI: /10.15468/dl.wkrbkj 
Gotelli, N. J., \& Colwell, R. K. (2001). Quantifying biodiversity: Procedures and pitfalls in the measurement and comparison of species richness. Ecology Letters , 4 (4), 379-391. DOI: 10.1046/j.1461-0248.2001.00230.x

Goudswaard, K. P. C., \& Witte, F. (1997). The catfish fauna of Lake Victoria after the Nile perch upsurge. Environmental Biology of Fishes , 49 (1), 21-43. DOI: 10.1023/A:1007311708377

Halmy, M. W. A., \& Salem, B. B. (2015). Species conservation importance index ( SCI ) for comparing sites ' conservation value at the landscape level. Brazilian Journal of Botany , 38 , 823-835. DOI: 10.1007/s40415015-0197-z

IUCN. (2012). IUCN Red List Categories and Criteria: (V 3.1, 2). Gland, Switzerland and Cambridge, UK: IUCN. iv + 32pp.

IUCN. (2020). IUCN Red List of Threatened Species. DOI: 10.5860/choice.49-6872

Kaufman, L. (1992). Catastrophic Change Rich in Freshwater Ecosystems. The lessons of Lake Victoria tropical ecosystem. BioScience ,42 (11), 846-858. DOI: 10.2307/1312084

Kaufman, L., \& Ochumba, P. (1993). Evolutionary and Conservation Biology of Cichlid Fishes as Revealed by Faunal Remnants in Northern Lake Victoria. Conservation Biology , 7 (3), 719-730. DOI: 10.1046/j.15231739.1993.07030719.x

Kirkpatrick, J. (1983). An lterative Method for Establishing Priorities for the Selection of Nature Reserves : An Example From Tasmania.Biological Conservation , 25 , 127-134. DOI: DOI: 10.1016/00063207(83)90056-3

Kishe-Machumu, M. ., Natugonza, V., Nyingi, D. ., Snoeks, J., Carr, J. A. ., Seehausen, O., \& Sayer, C. A. (2018). The status and distribution of freshwater fishes in the Lake Victoria Basin. In Catherine A. Sayer, L. Maiz-Tome, \& W. R. T. Darwall (Eds.), Freshwater biodiversity in the Lake Victoria Basin: Guidance for species conservation, site protection, climate resilience and sustainable livelihoods (1st ed., p. 26). Rue Mauverney 281196 Gland, Switzerland: IUCN. DOI: 10.2305/iucn.ch.2018.ra.2.en

Kudhongania, A. W., Twongo, T., \& Ogutu-Ohwayo, G. (1992). Impact of the Nile perch on the fisheries of Lakes Victoria and Kyoga.Hydrobiologia , 232 (1), 1-10. DOI: 10.1007/BF00014605

Linke, S., Turak, E., \& Nel, J. (2011). Freshwater conservation planning: the case for systematic approaches. Freshwater Biology , 56 , 6-20. DOI: 10.1111/j.1365-2427.2010.02456.x

Lippitsch, E. (2003). Redescription of "Haplochromis" nubilus (Teleostei: Cichlidae), with description of two new species.Ichthyological Exploration of Freshwaters , 14 (1), 85-95.

Lundberg, J. G., Kottelat, M., Smith, G. R., Stiassny, M. L. J., \& Gill, A. C. (2000). So Many Fishes, So Little Time: An Overview of Recent Ichthyological Discovery in Continental Waters. Annals of the Missouri Botanical Garden , 87 (1), 26. DOI: 10.2307/2666207

Marshall, B. E. (2018). Guilty as charged: Nile perch was the cause of the haplochromine decline in Lake Victoria. Canadian Journal of Fisheries and Aquatic Sciences , 75 (9), 1542-1559. DOI: 10.1139/cjfas2017-0056

Matthews, N. (2016). People and fresh water ecosystems : pressures, responses and resilience. Aquatic Procedia , 6 , 99-105. DOI: 10.1016/j.aqpro.2016.06.012

Mbabazi, D., Ogutu-Ohwayo, R., Wandera, S. B., \& Kiziito, Y. (2004). Fish species and trophic diversity of haplochromine cichlids in the Kyoga satellite lakes (Uganda). African Journal of Ecology ,42 (1), 59-68. DOI: $10.1111 / \mathrm{j} .0141-6707.2004 .00492 . x$

McIntyre, P. B., Liermann, C. A. R., \& Revenga, C. (2016). Linking freshwater fishery management to global food security and biodiversity conservation. Proceedings of the National Academy of Sciences of the United States of America , 113 (45), 12880-12885. DOI: 10.1073/pnas.1521540113 
Meier, J. I., Marques, D. A., Mwaiko, S., Wagner, C. E., Excoffier, L., \& Seehausen, O. (2017). Ancient hybridization fuels rapid cichlid fish adaptive radiations. Nature Communications , 8 (May 2016), 1-11. DOI: $10.1038 /$ ncomms14363

Mwanja, W. W., Armoudlian, A. S., Wandera, S. B., Kaufman, L., Wu, L., Booton, G. C., \& Fuerst, P. A. (2001). The bounty of minor lakes: The role of small satellite water bodies in evolution and conservation of fishes in the Lake Victoria Region, East Africa. Hydrobiologia ,458 , 55-62. DOI: 10.1023/A:1013167725047

Natugonza, V., \& Musinguzi, L. (2020). Freshwater biodiversity portal for Uganda. Retrieved from www.freshwaterbiodiversity.go.ug, version (01/2020)

NEMA. (2007). State of Environment Report for Uganda, NEMA, Kampala. 332pp.

Ogutu-Ohwayo, R, Wandera, S. B., Namulemo, G., \& Mbabazi, D. (1999). The role of satellite lakes in conservation of fish species diversity in the lake Kyoga basin. National Fisheries Resources Research Institute (NaFIRRI), Jinja, (Uganda). 20 pp. 1999. Retrieved from https://search.proquest.com/docview/1694976115?accountid=27308

Ogutu-Ohwayo, Richard. (1990). The decline of the native fishes of lakes Victoria and Kyoga (East Africa) and the impact of introduced species, especially the Nile perch, Lates niloticus, and the Nile tilapia, Oreochromis niloticus. Environmental Biology of Fishes ,27 (2), 81-96. DOI: 10.1007/BF00001938

Ogutu-Ohwayo, Richard. (1993). The effects of predation by Nile Perch, Lates niloticus L., with suggestions for conservation of Endangered Endemic Cichlids. Conservation Biology , 7 (3), 701-711. DOI: 10.1046/j.1523-1739.1993.07030701.x

Ogutu-Ohwayo, Richard, Wandera, S. B., Namulemo, G., \& Mbabazi, D. (1999). The role of satellite lakes in conservation of fish species divsersity in the Lake Kyoga Basin.

Oijen, M. J. P. Van. (1996). The generic classification of the haplochromine cichlids of Lake Victoria, East Africa The generic classification of the haplochromine cichlids of Lake Victoria, East Africa. Zoologische Verhandelingen Leiden, 300 , 57-110.

Oksanen, J., Guillaume Blanchet, F., Friendly, M., Kindt, R., Legendre, P., McGlinn, D., ... Wagner, H. (2019). vegan: Community Ecology Package. R package version 2.5-5. Retrieved from https://cran.rproject.org $/$ package $=$ vegan

Olowo, J. P., Chapman, L. J., Chapman, C. A., \& Ogutu-Ohwayo, R. (2004). The distribution and feeding ecology of the characid Brycinus sadleri in Lake Nabugabo, Uganda: Implications for persistence with Nile perch (Lates niloticus). African Journal of Aquatic Science,29 (1), 13-23. DOI: 10.2989/16085910409503788

Olwa, R., Nakiyende, H., Muhumuza, E., Bassa, S., Taabu-munyaho, A., \& Nkalubo, W. (2020). Ecology of the Critically endangered Singidia tilapia (Teleostei : Cichlidae : Oreochromis esculentus) of Lake Kayanja, Uganda, and its conservation implications. Journal of Threatened Taxa , 12 (10), 16251-16256. DOI: 10.11609/jott.5700.12.10.16251-16256

Omayio, D., \& Mzungu, E. (2019). Modification of Shannon-Wiener Diversity Index towards Quantitative Estimation of Environmental Wellness and Biodiversity Levels under a Non-comparative Scenario.Journal of Environment and Earth Science, 9 (3), 2224-3216. DOI: 10.7176/JEES

Reid, G. M., Contreras Macbeath, T., \& Csatadi, K. (2013). Global challenges in freshwater-fish conservation related to public aquariums and the aquarium industry. International Zoo Yearbook ,47 (1), 6-45. DOI: 10.1111/izy. 12020

Rosenzweig, L. M. (1995). Species diversity in space and time(2nd ed.). Cambridge University Press, Cambridge.

Sayer, C.A., Maiz-Tome, L., \& Darwall, W. R. T. (2018).Freshwater biodiversity in the Lake Victoria Basin: Guidance for species conservation, site protection, climate resilience, and sustainable livelihoods. 
Cambridge, UK, and Gland . Cambridge, UK and Gland, Switzerland: IUCN. xiv +226pp. DOI: 10.2305/IUCN.CH.2018.RA.2.en

Schofield, P. J., \& Chapman, L. J. (1999). Interactions between Nile perch, Lates niloticus, and other fishes in Lake Nabugabo, Uganda.Environment Biology of Fishes , 55 , 343-358. DOI: DOI: 10.1023/A:1007544017989

Schraml, E., \& Tichy, H. (2010). A new species of Haplochromis, Haplochromis katonga n. sp. (Perciformes: Cichlidae) from the Katonga River, Uganda. Aqua: International Journal of Ichthyology ,16 (3), 81-92.

Seehausen, O., Witte, F., Katunzi, E. F., Smits, J., \& Bouton, N. (1997). Patterns of the remnant cichlid fauna in southern Lake Victoria.Conservation Biology , 11 (4), 890-904. DOI: 10.1046/j.15231739.1997.95346.x

Souza Silva, M., Martins, R. P., \& Ferreira, R. L. (2014). Cave Conservation Priority Index to Adopt a Rapid Protection Strategy: A Case Study in Brazilian Atlantic Rain Forest. Environmental Management, 55 (2), 279-295. DOI: 10.1007/s00267-014-0414-8

Stager, J. C., Westwood, J., Grzesik, D., \& Cumming, B. F. (2005). A 5500-year environmental history of Lake Nabugabo, Uganda.Paleogeography, Palaeoclimatology, Palaeoecology ,218 (3-4), 347-354. DOI: $10.1016 /$ j.palaeo.2004.12.025

Sterner, R. W., Keeler, B., Polasky, S., Poudel, R., Rogers, M., \& Rhude, K. (2020). Ecosystem services of Earth's largest freshwater lakes. Ecosystem Services , 41 (January 2019), 101046. DOI: 10.1016/j.ecoser.2019.101046

Strayer, D. L. (2013). Endangered Freshwater Invertebrates.Encyclopedia of Biodiversity: Second Edition, 3 , 176-187. DOI: 10.1016/B978-0-12-384719-5.00270-7

Tognelli, M. F., Anderson, E. P., Segura, L. F. J., Correa, V., Javier, A., Vallejos, F. M. C., ... Navarro, F. A. V. (2019). Assessing conservation priorities of endemic freshwater fishes in the Tropical Andes region. Aquatic Conservation: Marine and Freshwater Ecosystems , 29 , 1123-1132. DOI: 10.1002/aqc.2971

van Alphen, J. J. M., Seehausen, O., \& Galis, F. (2004). Speciation and radiation in African haplochromine cichlids. In U. Dieckmann, M. Doebeli, J. Metz, \& D. Tautz (Eds.), Adaptive Speciation (Cambridge Studies in Adaptive Dynamics (pp. 173-191). Cambridge: Cambridge University Press. DOI: 10.1017/CBO9781139342179.010

Vanden Bossche, J. P., \& Bernacsek, G.. (1990). Sourcebook for the inland fishery resources of Africa: 1. CIFA Technical Paper (Vol. 1). Rome, FAO, 240p.

Wakwabi, E. O., Balirwa, J., \& Ntiba, M. J. (2006). Aquatic biodiversity of Lake Victoria basin. In E. O. Odada, D. O. Olago, \& W. O. Ochola (Eds.), Environment for Development: An Ecosystems Assessment of Lake Victoria Basin. (pp. 77-121). Nairobi: United Nations Environment Programme (UNEP), Pan African START Secretariat (PASS) Nairobi, Kenya.

Witte, F., \& Van Oijen, M. J. P. (1990). Taxonomy, ecology, and fishery of Lake Victoria haplochromine trophic groups. Zoologische Verhandelingen, 262 (1), 1-47.

WWF. (2014). Living Planet Report 2014 . Gland, Switzerland and Cambridge, UK.

WWF. (2020). Freshwater systems. DOI: 10.1016/b978-008043781-1/50006-2

Yasin, J. A., Kroeze, C., \& Mayorga, E. (2010). Nutrients export by rivers to the coastal waters of Africa: Past and future trends. Global Biogeochemical Cycles , 24 (2), 1-14. DOI: 10.1029/2009GB003568

Yi, Y., Yang, Z., \& Zhang, S. (2010). Ecological influence of dam construction and river-lake connectivity on migration fish habitat in the Yangtze River basin, China. Procedia Environmental Sciences ,2 , 1942-1954. DOI: $10.1016 /$ j.proenv.2010.10.207 
Table 1. Kruskal Wallis analysis of variances for IUCN categories and species richness followed by Dunn's multiple comparison test between waterbody categories

\begin{tabular}{|c|c|c|c|c|c|c|}
\hline & & & & & Dunn's test multiple comparisons $z$ (p-value) & Dunn's test multi \\
\hline Variable & $\chi^{2}$ & $\mathrm{df}$ & $p$-value & Effect size & Lakes & Rivers \\
\hline \multirow{2}{*}{ Critically endangered } & 24.6 & 2 & $<0.001$ & 0.27 & Large & $4.5(<0.001)$ \\
\hline & & & & & Small & $3.2(0.002)$ \\
\hline \multirow[t]{2}{*}{ Endangered } & 17.1 & 2 & $<0.001$ & 0.19 & Large & $4.1(<0.001)$ \\
\hline & & & & & Small & $1.1(0.38)$ \\
\hline \multirow[t]{2}{*}{ Vulnerable } & 24.4 & 2 & $<0.001$ & 0.26 & Large & $4.8(<0.001)$ \\
\hline & & & & & Small & $2.6(0.013)$ \\
\hline \multirow[t]{2}{*}{ Near threatened } & 13.5 & 2 & 0.001 & 0.16 & Large & $3.3(0.001)$ \\
\hline & & & & & Small & $0.6(0.811)$ \\
\hline \multirow[t]{2}{*}{ Least concern } & 16.4 & 2 & 0.0002 & 0.18 & Large & $3.9(0.001)$ \\
\hline & & & & & Small & $0.4(0.1)$ \\
\hline \multirow[t]{2}{*}{ Data deficient } & 19.8 & 2 & $<0.001$ & 0.22 & Large & $4.4(<0.001)$ \\
\hline & & & & & Small & $0.9(0.532)$ \\
\hline \multirow[t]{2}{*}{ Not evaluated } & 25.8 & 2 & $<0.001$ & 0.28 & Large & $4.4(<0.001)$ \\
\hline & & & & & Small & $1.2(0.367)$ \\
\hline \multirow[t]{2}{*}{ Species richness } & 18.6 & 2 & 0.001 & 0.20 & Large & $4.3(<0.001)$ \\
\hline & & & & & Small & $1.2(0.385)$ \\
\hline
\end{tabular}

\section{Figure legends}

Figure 1. Species composition in water bodies according to IUCN status and richness.

Figure 2. Species accumulation curve for fish species from 81 water bodies in Uganda

Fig 3. Rarity of species in the different water bodies in Uganda

Figure 4. Fish species composition in the three water body categories

Figure 5. Conservation Priority Index (CPIw) for evaluated water bodies in Uganda. 


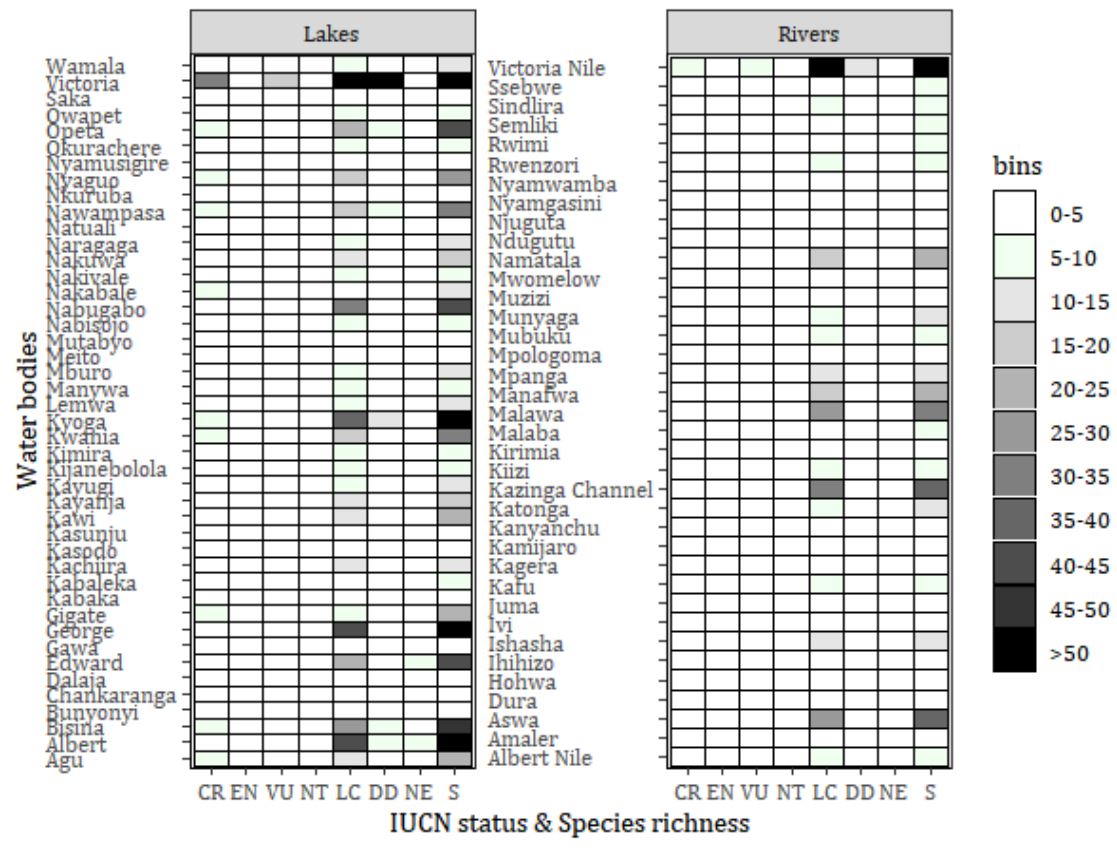

Fig 1. Species composition in water bodies according to IUCN status and richness.

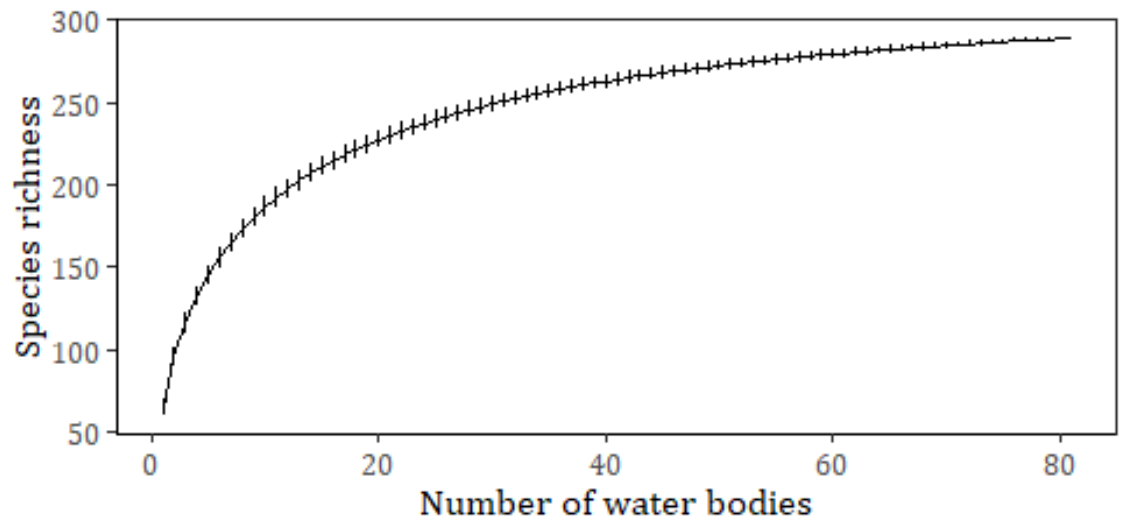

Fig 2. Species accumulation curve for fish species from 81 water bodies in Uganda 


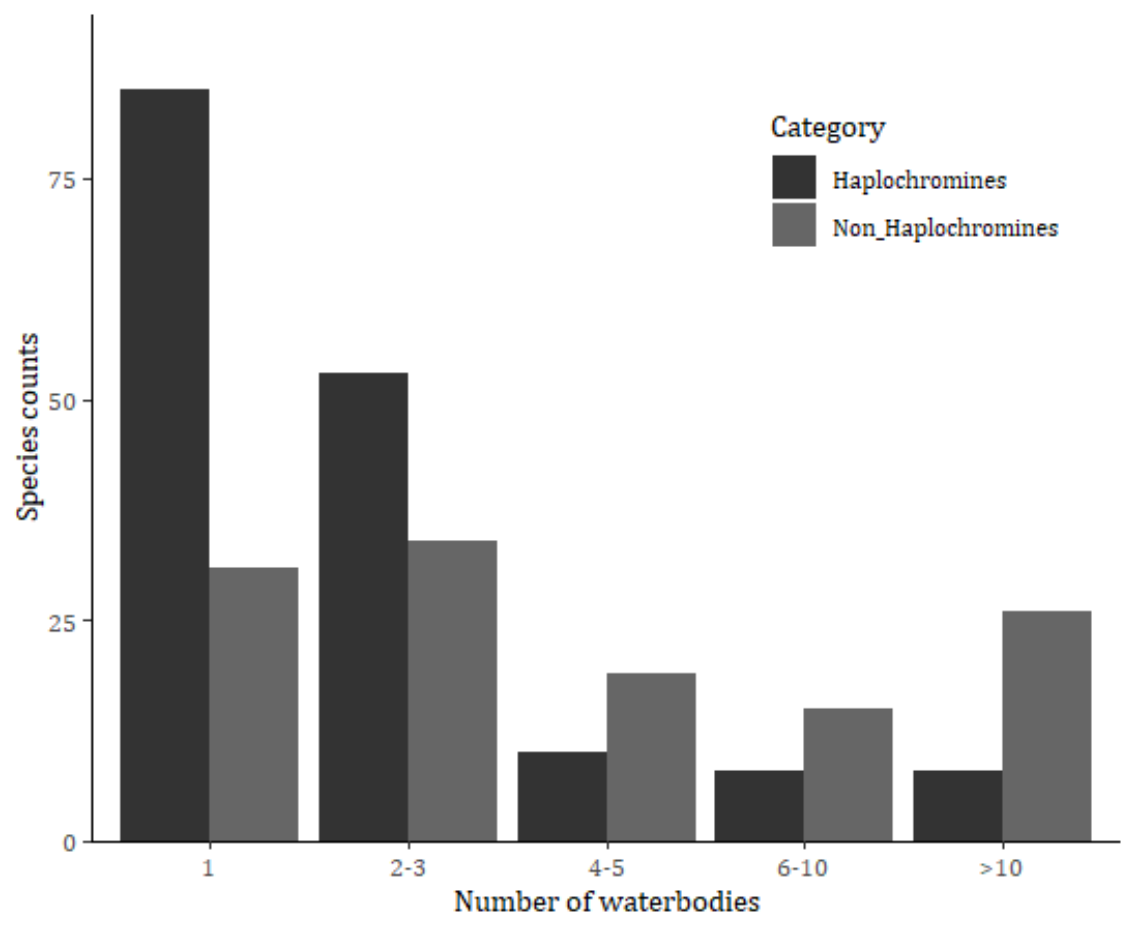

Fig 3. Rarity of species in the different water bodies in Uganda

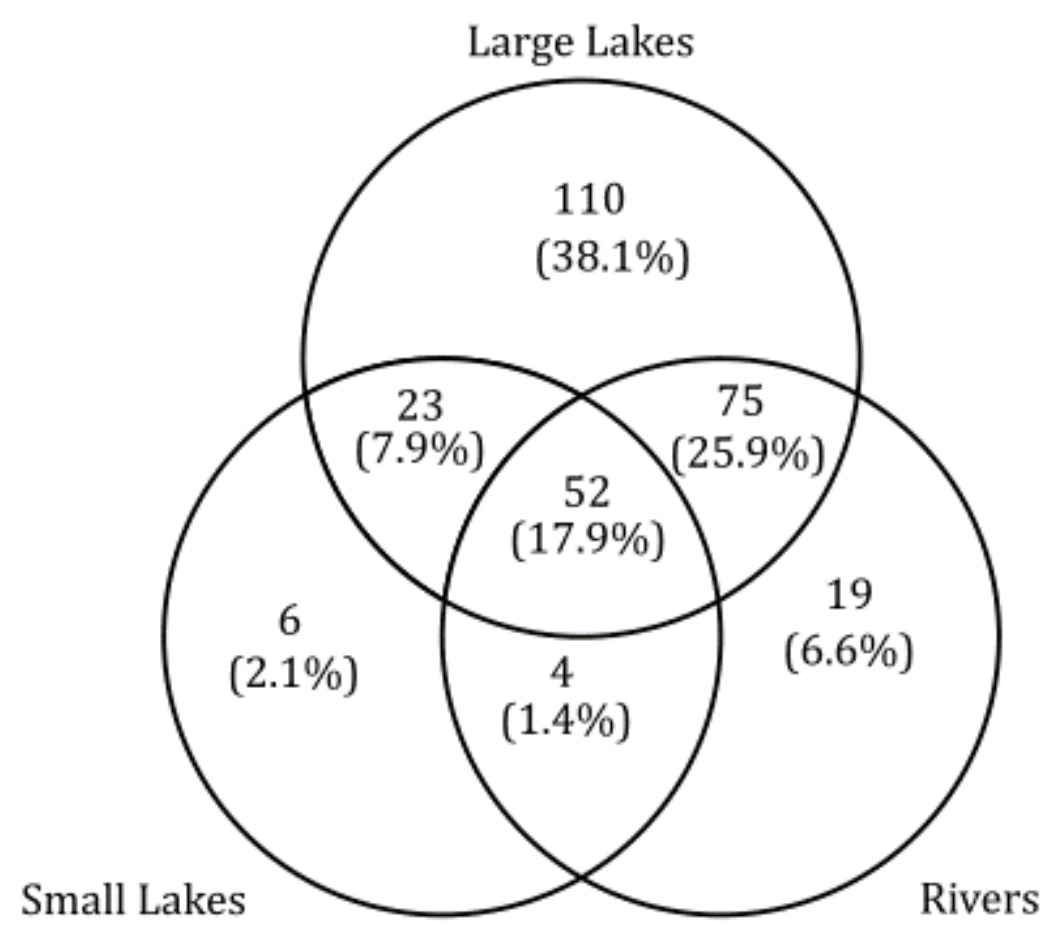

Fig 4. Fish species composition in the three water body categories 


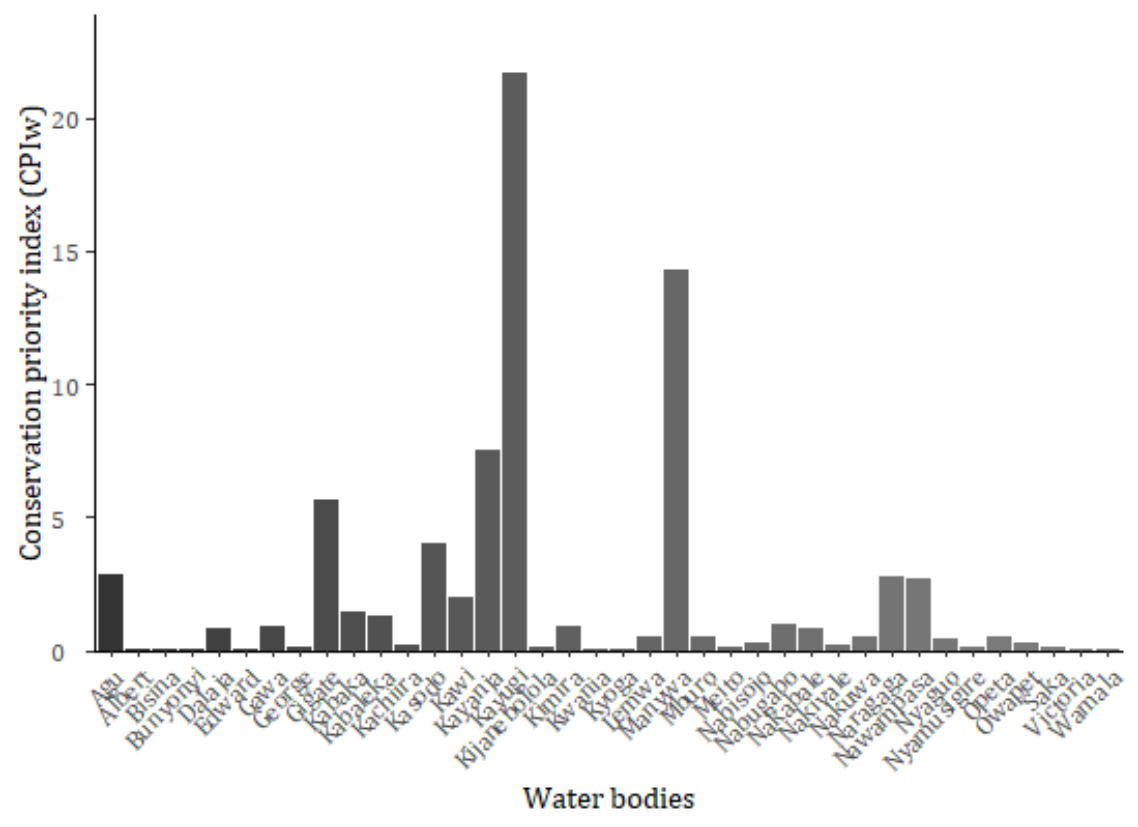

Fig 5. Conservation Priority Index (CPIw) for evaluated inland water bodies in Uganda. 